Владан Гавриловић Универзитет у Новом Саду Филозофски факултет Одсек за историју gavra1@yahoo.com
Оригиналан научни рад

примљено: 14. април 2014 прихваћено: 1. октобар 2014

\title{
ПРИМЕРИ МИГРАЦИЈА СРПСКОГ НАРОДА У УГАРСКЕ ПРОВИНЦИЈАЛНЕ ОБЛАСТИ 1699-1737."
}

Сажетак: Миграције српског народа у провинцијалне делове Угарске од Карловачког мира до аустро-турског рата 1737-1739. су биле много скромнијег карактера него Сеоба 1690. године. У оквиру извора и литературе смо се трудили да обухватимо појединачне примере и покажемо да су се осим породица, од којих су неке оставиле дубок траг у српској историји и култури (Руварци), насељавало и свештенство, не само из Србије, која је једном време (1718-1739) била под Аустријом. Такође су се досељавали трговци и занатлије који су својим присуством ојачали српску средину и етнички простор у Угарској и допринели коначном стварању и израстању српске грађанске класе у Монархији. Поновни већи талас насељавања српског народа на целокупну територију Угарске је уследио са избијањем новог аустро-турског рата 1737-1739. године, када су под патријархом Арсенијем IV Шакабентом, Срби поново били принуђени да напуштају своја огњишта.

Кључне речи: Карловачки мир, миграције, угарски провинцијал.

Велики бечки рат (1683-1699) је у току свог шеснаестогодишњег трајања у потпуности изменио дотадашњу геостратегијску и геополитичку слику Европе. Отоманска империја је поразом код Беча (1683) ушла из победничке у губитничку фазу, изгубивши докраја рата готово целокупне поседе у средњој Европи. Као нове силе, осим Аустрије и ојачане Венеције, јавиле су се Пољска и у завршној фази Русија, која је први пут после свог „мрачног доба“ изашла на европску дипломатску и политичку позорницу. То је допринело да се у будућности у потпуности отвори Источно питање, које је подразумевало коначну поделу турских поседа у Европи између нових, великих сила. ${ }^{1}$ У току рата као судионик се јавио и српски народ, који

\footnotetext{
* Текст је настао као фазни резултат на пројекту Војвођански простор у контексту европске историје (број 177002) Министарства просвете, науке и технолошког развоја Републике Србије. Такође, рад је настао на основу истраживања почившег академика Славка Гавриловића (1924-2008) чије ће име остати урезано великим словима у српској историографији.

${ }_{1}^{1}$ О Великом бечком рату и Карловачком миру вид. радове: Душан Ј. Поповић, Слика Војводине у 18 веку, Војводина II, Нови Сад б. г, 86-111; Исти, Племсто, Војводина II, 111-138; Глигор Станојевић, Србија у време Бечког рата, Београд 1976; Душан Ј. Поповић, Историја Срба у Војводини, књ. II, Нови Сад 1990;
} 
је умногоме путем Велике сеобе померен са својих природних и етничких станишта на север, у једну нову, за Србе непознату и искључиву католичку средину. ${ }^{2}$

У време Велике сеобе Срба (1690) навођењем података који се налазе у архивским изворима можемо закључити да извори говоре о главној групацији миграната на челу патријарха Чарнојевића и око њега која је износила 30.000-40.000 људи, не рачунајући оне хиљаде које су се на путу према Будиму и Коморану задржавале и настањивале по Бачкој, Срему, источној Славонији, Барањи и дуж Дунава, до ниже Будима. Са њима као и у походима принца Евгенија Савојског у Босну реална бројка избеглих Срба би била у оквиру процене великог историографа Илариона Руварца: од 70.000 до 80.000 душа. Зато сваки извор и свако име из овог почетног периода, после Великог бечког рата, представља несумњив и надасве значајан податак за нашу историографију. Велики део тог миграционог таласа се населио у оквирима нових војних граница у Угарској (Подунавској, Потиској и Поморишкој), које у овом раду нису предмет истраживања.

Миграције се, на основу тога, могу већ пратити и могу се извући одређени закључци на основу Пописа из 1697. године Сентандреје и Табана. У Попису доминирају презимена проистекла из надимка : по етничком пореклу - Рац, Бугарин, Арнаут; месту претходног боравка - Пожаревчанин, Ужичанин, Ћипровчанин, Призренац; или пак по занату којим су се бавили - ћурчија, кујунџија, колар, капамаџија, екмеџија. Сви ови занати су турски, што опет недвосмислено говори о томе одакле су пореклом становници Сентандреје и Табана. ${ }^{3}$ Такође се у пописима Будима и Пеште с почетка XVIII века могу наћи имена новопридошлих Срба: Симеон Рудничанин, Петар Ћипровац. ${ }^{4}$

Срби су у току и после Сеобе поново попунили просторе бившег дела Сегединског санџака, од Баје до Сегедина, у којима се српско становништво налазило и пре 1690. године. Доказе о новом доласку српског становништва можемо тражити у различитим протоколима, царинарницама, трговачким уговорима... У сваком од њих се помињу становници из Србије. Рецимо, 1700. године се помиње цела трговачка породица Ћипровац (Ћипровчани) у Баји, која је увозила вино у

\footnotetext{
Никола Самарџић, Франиуска и Турска (1687-1691), Београд 1992; Алекса Ивић, Историја Срба у Војводини, Нови Сад 1996 (поновљено издање); Жарко Димић, Велики бечки рат и Карловачки мир, Београд 1999; Дејан Микавица - Владан Гавриловић - Горан Васин, Знаменита документа за историју српског народа (1538-1918), Нови Сад 2007, 25-41; Дејан Микавица, Српско питање на угарском сабору, Нови Сад 2011, 11.

2 Владан Гавриловић, Велика сеоба Срба као миграциони талас у време Великог бечког рата, Истраживања, бр, 24, Нови Сад 2013, 167-177.

3 Према Попису из 1697. међу српским становништвом у Сентандреји било је много тзв. турских занатлија од чега највише: ћурчија - 34, дунђера - 22, табака - 21 , терзија - 16 , абаџија - 15 , капамаџија 13 , аласа -8 , касапа -8 , ковача 7 , екмесија (пекара) -7 , кујунџија -6 , колара -6 , воденичара-млинара 6 , ткача -6 , сабова -5 , папучара -5 , чибукџија -3 , сапунџија -3 , бербера -3 , опанчара-чаругџија -2 , и бачвара - 1. То је веома велики број занатлија, с обзиром на то да по Попису Табан и Сентандреја броје 742 одрасле особе и 716 њихових синова и кћери (Иван Јакшић - Карољ Јенеи, Грађа за историју Срба у Угарској после Сеобе 1690. године, Споменик САНУ, бр. СХХІІ, Београд 1981, 91-143; Федора Бикар, Сентандреја у огледалу прошлости, Нови Сад 2003, 37).

${ }^{4}$ Славко Гавриловић, Извори о Србима у Угарској с краја XVII и почетка XVIII века, Београд 2005, 70, 359.
} 
износу више стотина форинти. ${ }^{5}$ У попису Баје из 1727. године такође наилазимо на сличне податке о трговцима Србима, становницима Баје: Никола Ћипровац, Груја Мирковић, џелебџија, Ђурка Грк...

Занатлије, пореклом из Србије, које су недвосмислено дошле као избеглички (миграциони) талас у време Сеобе, првих година XVIII века налазили су посао и у мноштву српских манастира у Монархији, посебно на Фрушкој гори, који су ослобођени турског присуства са доласком новог становништва оживели. Тако је забележено да је кујунџија из Ћипровца Никола Недељковић 1705. године исковао и изрезбарио кивот за манастир Раваницу (Врдник). Недељковић је изгледа постао и званични кујунџија фрушкогорских манастира јер је две године касније (1707) забележено да је за манастир Крушедол исковао још један прелеп сребрни кивот. ${ }^{7}$

Осим занатлија и њихових миграција из Србије, у том почетном таласу у време Сеобе 1690. и после ње забележена су имена појединих свештеника који су куповали књиге богослужбеног карактера, већином из Русије, поседовали их и поклањали манастирима.

У вези с тим постоји запис из 1704. године на маргинама једног рукописа из манастира Врдника. У њему се потписао дијак Вељко Поповић, који за себе каже да је „отачаством же от блгарские земли от места Кратова“. 8 Запис о себи је оставио и јеромон Михаил, у служби јеромона Кирила у Сентандреји. Он, такође 1704. године, за себе каже да се „некогда закалуђерио у манастиру зовом Милешева, в храме взнесениа господа бога и спаса нашего Исус Христа“.”

Услед Ракоцијевог устанка (1703-1711) многи српски манастири у централној Угарској су били угрожени, а неки су, као манастир Грабовац, спаљени, при чему је манастирска братија нашла уточиште у фрушкогорским манастирима. Забележен је њихов боравак у манастиру Шишатовац, где су остали све до завршетка устанка 1711, а по неким другим изворима све до 1715 . године. ${ }^{10}$ Такође у више наврата, односно 1693, 1694. и 1718. године, у манастиру Велика Ремета су боравили монаси из манастира Раковица, а део књига овог манастира је остао и

\footnotetext{
${ }^{5}$ Славко Гавриловић - Иван Јакшић - Срета Пецињачки, Грђа о балканским трговиима у Угарској XVIII века, књ.1, Београд 1985, 159.

${ }^{6}$ Живан Сечански, Пописи становништва Бачке током осамнаестог века, Београд 1952, 235.

${ }^{7}$ Натпис на кивоту (ковчегу за чување освећеног хлеба) из 1705. у манастиру Раваници (Врднику) гласи: ,, Евеи свашчении кивот монастира Раванице, дому спасова и сватаго кнеза Лазара сдела се в лето от рождества Христова .аче [1705 - бројна вредност слова]. Тогда же светителствујушчу и србски престол правејшчу сватеишии патриарх кир хажи Арсение и при Игумену Димитрију јеромонаху и проигумену Филипу јеромонаху. И за рукоделние плати Леонтие монах бог да га прости. Сему делу бист настоиник Стефан еромонах. И потруди се маистор Никола Неделковић от Ћипровац“. За крушедолски кивот из 1707. је забележено следеће: „Артофорион сеи светии, важделех сатворити, иже недостоини с изабрании сести, Аганцов светих хранити, Крушедола манастира обител с[ве]т[у]. Уже лету текушча .ачз - го[дине] [1707 - бројна вредност слова]. Месеца маиа числа е - го[дине] [5 - бројна вредност слова]. Сему делател Никола Неделковић“ (Љубомир Стојановић, Стари српски записи и натписи, књ. 2, Београд 1983, док. бр. 2169, 17; Павле Штрасер, Ктитори и приложници манастира Крушедол, Сремски Карловци 2000, 29).

${ }^{8}$ Кьига се налазила у власништву дијака Поповића, који је 1704 . био у Будиму. Нисмо у могућности да утврдимо када је рукопис стигао у манастир Врдник (љ. Стојановић, Нав. дело, док. бр. 2129, 9).

9 Љ. Стојановић, Нав. дело, док. бр. 2130, 9.

${ }_{10}$ Павле Штрасер, Ктитори и приложници манастира Шишатовияа у XVIII веку, Сремски Карловци 1984,7 .
} 
данас у поседу манастира Велике Ремете. ${ }^{11}$

Фрушкогорски манастири су уједно били и расадници културе и носиоци српске националне идеје и сна о обнови српске државе. У њих су долазили свештеници и ђакони из Србије, да би стекли свештеничко, али и културнонационално образовање. Тако је забележено да је код бешеновачког монаха Исаије 1735. године учио књигу свештеник Мојсије из села Преке Баре код Ваљева. ${ }^{12}$

После тог почетног, масовног таласа у време Сеобе и непосредно после ње, са склапањем Карловачког мира с почетка 1699. године, према којем је Отоманска царевина задржала Босну, југоисточни Срем, Банат и Србију, ${ }^{13}$ миграције из ових крајева у Аустријску царевину попримиле су вид ретких, појединачних, или мањих групних исељавања претежно у новоосвојену Славонију и део Срема који је припао Аустрији. На целом новоосвојеном подручју, тзв. Neoaquistica, становништво је било несигурно, небрањено и умногоме застрашено. Томе је осим лошег пријема српског народа на угарске територије допринео и Ракоцијев устанак, када је из Бачке и Барање дошло до великог померања српског становништва у Славонију, Срем, па чак и под Турке у Банату. У том смислу речито сведочи барањски епископ Никанор Милентијевић који је на пролеће 1711. године писао царском команданту у Сигету, генералу Јохану Јозефу Хуину, како су се тамошњи Срби разбежали највише у Славонију, а неки прешли чак и на турску (босанску) страну. ${ }^{14}$

Што се тиче мигрирања из Србије, у расположивим изворима забележено је само неколико случајева. Тако је Андрија Вулић (Вуловић), трговац из Чалме у Срему, сведочио 1791. године пред сремским жупанијским већем о пореклу своје породице и између осталог навео и то да су његови преци Георгије и Вукота Вулић 1711. прешли из Србије у Срем и довели велику множину отоманских поданика са собом (magnum ottomanicorum subditorum). Због тога је, како даље сведочи Андрија Вулић, његов предак Георгије Вулић 1715. постао граничарски командант у Рачи и учествовао у аустро-турском рату 1716-1718. године, у ком је исказао велику храброст при опсади Футога, Паланке и Београда, где су под њим убијена два коња.

\footnotetext{
${ }^{11}$ Манастир је почетком XVIII века имао образоване монахе, пре свих јеромонаха Пахомија Месићанина, који је преписао 1702. један молитвеник и 1705. један минеј. Ипак је оскудица у књигама била стална, па су се обнављале раније постојеће. Када је манастир скоро стао финансијски на своје ноге, наступио је нови аустро-турски рат 1716-1718, у коме су после битке код Петроварадина, августа 1716. Турци, из обести, попалили и део фрушкогорских манастира, пре свих Крушедол и Велику Ремету, па је манастир двадесетих година XVIII века поново обнављан (Павле Штрасер, Ктитори и приложници манастира Велика Ремета, Сремски Карловци 2004, 10; Душко М. Ковачевић, Велика Ремета манастир Светог Димитрија, Земун 2013, 18-24).

12 Душко М. Ковачевић, Бешеново, Сремска Митровица - Нови Сад 2011, 27.

13 Занимљиве су поједине одредбе мира које се рецимо односе на Тител, као погранично место у Бачкој у аустријским рукама према Банату, као и Темишвар, дубоко у банатској територији, односно Отоманској империји. За Тител се напомиње да се убудуће не утврђуе него што је „сада“ (1699) утврђен, док се за Темишвар, над којим би Турци требало да имају потпуну контролу, каже: „да све што се налази на подручју Темишвара, као и територија омеђена рекама Моришом и Тисом, почевши од ердељске границе из времена пре овога рата, нека буде од стране поменутог ћесара [аустријског цара] порушено, с тим да се убудуће не подижу, и нека се речена покрајина [Банат] потпуно очисти и да се одсада нити поменута места нити остала мања и већа места у близини обала Мориша и Тисе не претварају и не изграђују у тврђаве“ (Ж. Димић, Велики бечки рат и Карловачки мир, 302-303).

${ }^{14}$ Hofkammerarchiv, Wien, Acta Expeditorum, 1711, Juny, No 120, fol. 1 (даље: HКA).
} 
Његов брат Вукота погинуо је касније у рату против Француза. ${ }^{15}$

Тих година, тачније 1716/1717, из Пожаревца је у Срем пребегао са родитељима као дечак Викентије Поповић, потоњи епископ вршачкокарансебешки. ${ }^{16}$ Трећа значајна породица која се доселила из Србије били су Руварци. Они су почетком XVIII века дошли из Врања, привремено се настанили у Тршић, да би 1715. на челу с Вукашином Руварцем избегли у Печуј, а одатле се раселили по Срему и Банату. ${ }^{17}$ Сличан ток сељења и исељавања имала је и позната породица Берић, о којој је записано: „Праотац Берислав живио је у Босни у Ломовити. Унук његов Радојко пресели се у Сјеницу близу манастира Косанице гди му је син Божа монахом постао. Одтуд после избегне због насилија турског л[ета] 1716. са својом породицом и стани се у Банату са стоком својом на унки гди сада село Маргита лежи. Ненад такође унук Берислава пресели се из Босне у Мачву одкуд његов унук Мирко, Сретенов син дође у Панчево са неким калуђером гди се после нађе случајно са породицом. Кћи Миркова Маргита пала је као жртва Турком на унки у стану Радојковом мртва - и од њеног имена добило је село прозвања Маргита“. 18

До већег померања становништва дошло је у току аустро-турског рата 1716-1718. године и после. О пребегавању из Србије у Срем, Кузмин и околину, хроничар Петар Руњанин оставио је речито сведочанство: „У љету 1716. у време турске војне велика част народа из Турске избјегоше, на љевој страни Саве у держави Аустријској прибјежиша у збегови тражећи, њеколико фамилија у овом предјелу, у густој шуми поселило се. Овај предјел указо се тому способан, јер густе шуме са барама, тресетима, ритовима пуним терске, рогоса и ивовине испресецан, био је тамо прибегшим и насељеним фамилијама обрана против турски коњаника, и

\footnotetext{
${ }^{15}$ Андрија Вуловић се у изворима први пут помиње 1758. кад је као „господар Андреј Вулович“ из Чалме даровао манастиру Кувеждину петохлебницу од масивног сребра. Спадао је међу богатије трговце у Срему у другој половини XVIII века. Бавио се сточном и дућанском трговином, закупљивањем крчми, као и куповином и продајом кукуруза. Убили су га разбојници на свиреп начин заједно са својим слугом 1796 (Zagrebački arhiv, Sremska županija, acta congregationalia, 351/1792 (AHZ, Sremska, а. с.); Славко Гавриловић, Вуловић, Андрија, Српски биографски речник, књ. 2 (В-Г), Нови Сад 2006, 510).

16 Деведесетих година XVIII века Викентије се са породицом настанио у околину Вуковара, где је код магистра (учитеља) Богића учио књигу. Замонашио се у манастиру Шишатовцу 6. октобра 1728. У игумана манастира Шишатовца произвео га је 12. августа 1739. патријарх Арсеније IV Шакабента, а митрополит Павле Ненадовић прогласио га 28. маја 1751. за архимандрита овог манастира. Као настојатељ манастира Шишатовца о свом трошку је подигао садашњи храм и као велики књигољубац оставио манастиру више драгоцених књига осамнаестог века. Хиротонисан је за вршачког епископа у Карловцима 4. октобра 1774. За време његовог епископата установљена је конзисторија у Вршцу а саграђене саборна црква и епископска резиденција са капелом. Умро је 16. децембра 1785. у Вршцу. Прво је сахрањен у манастиру Месић, да би испунивши његову последњу жељу његове посмртне остатке 1810. пренели у манастир Шишатовац, о коме се он за живота највише старао (Владика Сава, Српски јерарси од деветог до двадесетог века, Београд-Подгорица-Крагујевац 1996, 75).

${ }^{17}$ Из ове породице Руварац су потекли у другој половини ХІХ века Коста Руварац, песник и идејни творац Уједињене омладине српске, архимандрит Иларион Руварац, отац модерне српске историографије, и Димитрије Руварац, историчар, вредни настављач Иларионове традиције и марљиви сакупљач историјских извора (Димитрије Руварац, Аутобиографија и библиографија, Нови Сад 1927, 43; Зборник „Браћа Рувараи у српској историографији и култури“, Нови Сад - Сремска Митровица 1997.

18 Запис о пореклу породице је оставио свештеник Илија Берић средином XIX века (Славко Гавриловић, Запис о роду Берића, Зборник Матице српске за историју, св. 50, Нови Сад 1994, 197-198).
} 
тамо спасеније своје находиле су. Поред тога, недалеко Кузмина пребегли су и неки калуђери из манастира Раче који су на брежуљку ћелиће за своје обитаније направили и за време војне живели“. ${ }^{19}$ Боравак монаха из Србије 1716. је такође забележен у манастиру Кувеждину. У њему су боравили због турске опасности монаси из манастира Сланац код Београда. ${ }^{20}$

Нема ближих података колико се тих „прекосаваца“ расуло по Срему непосредно у време рата 1716-1718. и у првим годинама после завршетка рата. Рецимо, у Старој Руми су 1720. забележене три породичне старешине са презименом Прекосавац - Милинко, Јосим и Мали Прекосавац. ${ }^{21}$ У Митровици у исто време (1722-1725) је забележено да има досељеника из Ужица (1), из Ноћаја у Мачви (3), док се 14 домаћинстава са 135 говеда и 430 оваца и коза доселило из Херцеговине. $^{22}$ Према табели о насељавању, у Митровицу се 1733 . доселило 39 мушких глава са породицама из: Србије 14, Босне 8, Македоније 8, Бугарске 3, Грчке 2 , Херцеговине 2 и из Војне крајине у Хрватској 2 члана. ${ }^{23}$ Из тужбе шабачког коморског провизора из 1731. дознајемо да су из његовог провизората од 1725. до 1731. у Срем пребегле 54 пореске главе, и „да их је било и у Мартинцима, а кад су чули да их он потражује од Митровачког спахилука, побегли су у Ноћај, да би се, потом, вратили у Срем“. ${ }^{24}$

Из пописа Срема из 1736. године могуће је извући закључак о појединцима који су стигли из Србије у периоду од Сеобе 1690. до датог времена, на основу њихових надимака, некад чак и презимена, као што су: Мачванин (22 кућедомаћина с тим надевком), Лесковчанин (6), Ваљевчанин (4), Шапчанин (3), Зворничанин (2), Сокољанин (2), Београђанин и Бирчанин (1). Такође је забележено 36 кућедомаћина под називом „Бугар, Бугарски, Бугарчић“, које су носили домаћини из источне Србије. У Попису је забележено и 20 кућедомаћина Херцеговаца и 19 Црногораца, као пореских глава, носилаца породице. ${ }^{25}$

У Бачкој су миграције биле још мањег обима и до тридесетих година XVIII века забележено је наводних Бугара (односно Источносрбијанаца) 28 домаћина, односно породица: Белградаца 8, Херцеговаца 6, Ваљеваца 5, Старовлашана 4, Прекосаваца 3, Пожаревчана 3, Арнаута (Срба са Косова и Метохије) 3, Мачвана 2, Ћипровчана 2, Вишњичана 2, Рудничана 1, Ресаваца, Крушевчана, Полимаца, Црнобараца и Поречана 1 и Грка-Цинцара 2 домаћина. ${ }^{26}$

Такође је због различитих околности било пребегавања (мигрирања) из Баната у Бачку и обрнуто. Из жупаније сељаци су бежали због угњетавања од стране спахијске и коморске власти у Војну границу, а из Границе се бежало у цивилне, провинцијалне области због тегоба војничког живота, а потом и због контрибуције

${ }^{19}$ Петра Руњанина историја села Кузмина, (приредио Никола Радојчић), Сремски Карловци 1936, 14-15, $22-23$.

${ }^{20}$ љ. Стојановић, Нав. дело, док. бр. 2297, 39.

${ }^{21}$ Славко Гавриловић, Рума - трговиште у Срему 1716-1848/49, Нови Сад 1969, 10.

${ }^{22}$ Славко Гавриловић, Митровица - трговиште у Срему XVIII и ХIX века (1716-1848), Београд 1994, 9.

${ }^{23}$ Исто, 10.

${ }^{24}$ Славко Гавриловић, Срем од краја ХVII до средине XVIII века, Нови Сад 1979, 169.

${ }^{25}$ Душан Ј. Поповић, Срби у Срем у до 1736/37, Београд 1950, 155-236.

${ }^{26}$ Ж. Сечански, Пописи становништва, passim. 
(пореза), коју су граничари сматрали неспојивом са војним статусом у Аустријској царевини. У време Ракоцијевог устанка из Бачке се пребегавало у Банат, који је још био под турском власти, а касније, када је Банат прешао у руке Аустрије (1718), пребегавање се наставило, јер је стање у коморском Банату изгледало сношљивије од коморског па и од граничарског у Бачкој. Али исто тако, а ипак у мањој мери, било је пребегавања и у супротном правцу, односно из Баната у Бачку, тј. испод коморске администрације Баната под коморску и граничарску власт у Бачкој. О томе сведоче објављени списи од 1719. до 1725. године, према којима је из Бачке у Банат пребегло 346 пореских глава, док је из Баната у Бачку пребегло свега 197 глава. ${ }^{27}$ Године 1725. највише пребега из Баната у Бачку било је из Кањиже, Чанада, Чоке, Елемира, Арадца, Ечке, Итебеја, Бечеја, од којих се већина населила у Гардиновце, Дорослово, Турију, Аду и Крстур. ${ }^{28}$ У Чуругу је живело шест породица за које је изричито забележено да су се 1725 . године населили из Баната. ${ }^{29}$ Из пописа извршеног 1733. године види се да је дошло до новог таласа пресељавања из Баната у Бачку, и то првенствено из Бечкеречког и Чанадског округа, највише из Бечкерека, Чанада, Кумана, Пардања, Сечња, те се највећи број тих миграната населио у Чиб, а знатно мањи део у Турију и Каравуково. ${ }^{30}$

Сталну али ипак појединачну или мање групну миграцију су чинили „турски“ трговци који су се, од доношења повољних трговинских уговора између Аустрије и Турске у оквиру Пожаревачког мира 1718, настањивали на територију Монархије, посебно у Срем и доњу Славонију.О њиховој бројности најбоље сведочи попис Срема из 1736. који помиње турске трговце, тзв. „Грке“, у Земуну, Сурчину, Белегишу, Вогњу, Илоку, Вуковару, Митровици, нарочито у Иригу и Карловцима. У Иригу се чак један део града по њима прозвао „Грчка мала“. ${ }^{31}$ Број турских трговаца у Угарској је стално растао, тако да су према пописима из шездесетих година XVIII века они достигли завидну цифру од 17.000 до 18.000 породица. ${ }^{32}$ У двадесетим и тридесетим годинама XVIII века број „Грка“ у Вуковару се кретао од три до девет. Тако су 1733. забележени калајџија Живан, и капамаџије Пешо Грк и Грујо Грк. Њима су се 1737. придружили капамаџије Тасо Грк, Тодор Грк и Ристо Грк, казанџија Манојло, Михајло Арнаутин и Димитрије Папа Поповић. ${ }^{33}$

Више турских трговаца је забележено у Славонији, јер су за њих околности до стварања жупанија 1745. биле знатно повољније. У Осијеку, већ у најраније доба

\footnotetext{
${ }^{27}$ Срета Пецињачки, Документи о бачко-банатским миграчијама 1719-1725. године, Зборник Матице српске за историју, бр. 6, Нови Сад 1972, 105-116; Мирко Митровић, Насељавање и колонизација Војводине 1690-1945. године, Годишњак Друштва историчара Војводине, Нови Сад 1982, 195-291.

${ }^{28}$ С. Пецињачки, Нав. дело, 112-115.

29 Душан Ј. Поповић, Срби у Банату до краја осамнаестог века, Београд 1955, 76.

${ }^{30}$ HKA, Hoffinanc Ungarn, r. Nr. 664, März 1733, fol. 215-216; Владан Гавриловић, О пребегавању српског становништва из Баната у Бачку током прве половине XVIII века, Зборник Матице српске за историју, бр. 83, Нови Сад 2011, 119-127.

${ }^{31}$ Попис је само делимичан у односу на турске трговце јер су пописани само стално настањени, а велики број њих је продавао „на мало“, торбарећи од места до места, без трајног станишта (Д. Ј.Поповић, Срби у Сремy, passim; Славко Гавриловић, Прилог историји трговине и миграчије Балкан-Подунавље XVIII и ХІХ столећа, Београд 1969, passim.

${ }^{32}$ С. Гавриловић, Прилог историји трговине и миграције, 9.

${ }^{33}$ С. Гавриловић, Исто, 27.
} 
ослобођења Славоније, у време 1697-1702, већ су се настанили турски трговци: Христо Јерменин и Димитрије Грк. Према Попису из 1722. у Осијеку је било преко 10 трајно настањених „Грка““ трговаца. ${ }^{34}$

Као што се може закључити, миграције српског народа у провинцијалне делове Угарске од Карловачког мира до аустро-турског рата 1737-1739. су биле много скромнијег карактера него Сеоба из 1690, али су оне, иако појединачне, понекад чак и стихијске, умногоме ојачале српску средину и етнички простор у Угарској и допринеле коначном стварању и израстању српске грађанске класе у Монархији.

Извори и литература:

Извори:

Гавриловић, Славко - Јакшић, Иван - Пецињачки, Срета, Грађа о балканским трговщима у Угарској ХVIII века, књ. 1, Београд 1985.

Гавриловић, Славко, Вуловић, Андрија, Српски биографски речник, књ. 2 (В-Г), Нови Сад 2006.

Гавриловић, Славко, Извори о Србима у Угарској с краја XVII и почетка XVIII века, Београд 2005.

Zagrebački arhiv, Sremska županija, acta congregationalia, 351/1792.

Руварац, Димитрије, Аутобиографија и библиографија, Нови Сад 1927.

Стојановић, Љубомир, Стари српски записи и натписи, књ. 2, док. бр. 2129, 2130, 2169, 2297.

Hofkammerarchiv, Wien, Acta Expeditorum, 1711, Juny, No 120, fol. 1.

Hofkammerarchiv, Wien, Hoffinanc Ungarn, r. Nr. 664, März 1733, fol. 215-216.

Литература :

Бикар, Федора, Сентандреја у огледалу прошлости, Нови Сад 2003.

Владика Сава, Српски јерарси од деветог до двадесетог века, Београд-ПодгорицаКрагујевац 1996.

Гавриловић Славко, Срем од краја XVII до средине XVIII века, Нови Сад 1979.

Гавриловић, Владан, Велика сеоба Срба као миграциони талас у време Великог бечког рата, Истраживања, бр. 24, Нови Сад 2013.

Гавриловић, Владан, О пребегавању српског становништва из Баната у Бачку током прве половине XVIII века, Зборник Матице српске за историју, бр. 83, Нови Сад 2011.

Гавриловић, Славко, Запис о роду Берића, Зборник Матице српске за историју, св. 50, Нови Сад 1994.

Гавриловић, Славко, Митровииа - трговиште у Срему XVIII и XIX века (1716-1848), Београд 1994.

Гавриловић, Славко, Прилог историји трговине и мигращије Балкан-Подунавље XVIII и XIX столећа, Београд 1969.

${ }^{34}$ Исто, 50. 
Гавриловић, Славко, Рума - трговиште у Срему 1716-1848/49, Нови Сад 1969.

Димић, Жарко, Велики бечки рат и Карловачки мир, Београд 1999.

Зборник „Браћа Рувараи у српској историографији и култури“, Нови Сад - Сремска Митровица 1997.

Ивић, Алекса, Историја Срба у Војводини, Нови Сад 1996 (поновљено издање).

Јакшић, Иван - Јенеи, Карољ, Грађа за историју Срба у Угарској после Сеобе 1690. године, Споменик САНУ, бр. СХХІІ, Београд 1981, 91-143.

Ковачевић Душко М., Бешеново, Сремска Митровица - Нови Сад 2011.

Ковачевић Душко М., Велика Ремета манастир Светог Димитрија, Земун 2013.

Микавица, Дејан - Гавриловић, Владан - Васин, Горан, Знаменита документа за историју српског народа (1538-1918), Нови Сад 2007.

Микавица, Дејан, Српско питање на угарском сабору, Нови Сад 2011.

Митровић, Мирко, Насељавање и колонизаиија Војводине 1690-1945. године, Годишњак Друштва историчара Војводине, Нови Сад 1982.

Пецињачки, Срета, Документи о бачко-банатским миграиијама 1719-1725. године, Зборник Матице српске за историју, бр. 6, Нови Сад 1972.

Поповић Душан Ј., Историја Срба у Војводини, књ. ІІ, Нови Сад 1990.

Поповић Душан Ј., Племсто, Војводина II, Нови Сад, б. г.

Поповић Душан Ј., Слика Војводине у 18. веку, Војводина II, Нови Сад б. г.

Поповић Душан Ј., Срби у Банату до краја осамнаестог века, Београд 1955.

Поповић Душан Ј., Срби у Срему до 1736/37, Београд 1950.

Радојчић, Никола, Петра Руњанина историја села Кузмина, Сремски Карловци 1936.

Самарџић, Никола, Франиуска и Турска (1687-1691), Београд 1992.

Сечански, Живан, Пописи становништва Бачке током осамнаестог века, Београд 1952.

Станојевић, Глигор, Србија у време Бечког рата, Београд 1976.

Штрасер, Павле, Ктитори и приложници манастира Шишатовиа у XVIII веку, Сремски Карловци 1984.

Штрасер, Павле, Ктитори и приложници манастира Крушедол, Сремски Карловци 2000.

Штрасер, Павле, Ктитори и приложници манастира Велика Ремета, Сремски Карловци 2004. 


\title{
EXAMPLES OF SERBIAN MIGRATIONS TO HUNGARIAN PROVINCIAL DISTRICTS 1699-1737
}

\begin{abstract}
Summary
From the Treaty of Karlowitz to the Austro-Turkish War of 1737-1739 the migrations of Serbian people in the provincial districts of Hungary were far more modest in number than in the Migration of 1690 . Based on the sources and literature we made efforts to include those particular examples and show that besides families, of which some left deep trace in Serbian history and culture (the Ruvarac family), the clergy settled here as well; and not only the clergy from Serbia, which was at one time under Austrian rule (1718-1739). Moreover, there was a great influx of merchants and craftsmen, whose settlement fortified Serbian ethnic territory in Hungary and contributed to final creation and establishment of Serbian middle class within the Monarchy. Another larger wave of migration of Serbian people in overall territory of Hungary followed the outbreak of a new Austro-Turkish war in 1737, during which Serbs were again forced to leave their homes led by patriarch Arsenije IV Šakabenta.
\end{abstract}

Keywords: Treaty of Karlowitz, migrations, Hungarian provinces. 